\title{
Assessment of Water Quality and Pollution Index in Coastal Waters of Mimika, Indonesia
}

\author{
Rosye Hefmi Rechnelty Tanjung ${ }^{1}$, Baigo Hamuna ${ }^{2 *}$, Alianto ${ }^{3}$ \\ 1 Department of Biology, Cenderawasih University, Kamp Wolker Street, Jayapura City 99351, Papua, Indonesia \\ 2 Department of Marine Science and Fisheries, Cenderawasih University, Kamp Wolker Street, \\ Jayapura City 99351, Papua, Indonesia \\ ${ }^{3}$ Department of Fisheries, University of Papua, Gunung Salju Street, Manokwari 98314, West Papua, Indonesia \\ * Corresponding author's e-mail: bhamuna@yahoo.com.sg
}

\begin{abstract}
A good water quality is essential to sustaining the life of the organisms. The determination of water quality is needed as a direction to monitoring the water pollution. The purpose of this study is to examine the quality of the water and to determine the water pollution index based on the physicochemical parameters in Mimika waters, Indonesia. The sampling of water quality was carried out in October 2016 at six stations (Moga, Puriri, Inaoga, Keakwa, Atuka and Pomako waters). Then, the results were compared with the standard of sea water quality for biota marine based on the Decree of the Minister of Environment No. 51 year 2004. This study showed that the physicochemical parameters of the waters, such as water turbidity, $\mathrm{BOD}, \mathrm{NH}_{3}$ and heavy metals ( $\mathrm{Hg}, \mathrm{As}, \mathrm{Cd}, \mathrm{Pb}, \mathrm{Cu}, \mathrm{Zn}, \mathrm{Ni}$ and $\mathrm{Cr}$ ), are still appropriate to the biota marine in all study stations. However, there is a parameter for which the quality standards were exceed in all locations, including water salinity for coral and seagrass, $\mathrm{NO}_{3}, \mathrm{PO}_{4}$ and $\mathrm{H}_{2} \mathrm{~S}$. The result of pollution index calculation at coastal waters Mimika are classified as lightly polluted (Keakwa and Pomako waters), and moderately polluted (Moga, Puriri, Inaoga and Atuka waters) with the pollution index values of 3.51 to 6.95. It is important to notice that the parameters of quality standards which had been exceed such as $\mathrm{NO}_{3}, \mathrm{PO}_{4}$ and $\mathrm{H}_{2} \mathrm{~S}$ are the environmental parameter for nutrient elements and can trigger eutrophication in the waters.
\end{abstract}

Keywords: water quality; water pollution index; physicochemical parameters; quality standards; marine biota; Mimika waters

\section{INTRODUCTION}

The main issue in the territorial waters is the condition of polluted waters, which can reduce the quality of the aquatic environment. The organic and inorganic pollutants in the coastal waters can lead to the quality of water such as the biological function degradation and make an impact to the water. The water quality depends on the environment and it is determined based on the physicochemical parameters of the waters (Hamuna et al., 2018). Organic and inorganic materials flow through rivers, upwelling processes, vertical mixing of water masses and anthropogenic sources such as agriculture, aquaculture, industry, fisheries activities, fuel use and vessel ballast wa- ter discharge (Chen et al., 2007; Tjahjono et al., 2017; Drira et al., 2017).

The development of buildings in the Mimika region, especially in coastal areas has an influence on the existence of ecosystems in the lowland and coastal areas (IFACS, 2014). In addition, the high activity in the coastal and marine waters of Mimika can make an impact on the pollution and the quality of coastal and marine waters. The number of large and small rivers flowing in coastal waters will bring industrial waste, agricultural waste and anthropogenic waste from the mainland. These conditions can disturb the potential in coastal and marine waters as a source of food for the community. 
The research on the sea waters quality of Mimika and its surroundings was carried out by Ilahude et al. (2004), Herlisman et al. (2010) and Pranowo et al. (2013). However, only a few environmental parameters were reported in these studies. On the other hand, the water quality information is very important in supporting the planning and management of coastal and marine areas. This water quality assessment can provide information whether the quality water can threaten the utilization biota marine. The assessment of water quality is a complex process and involves a variety of water parameters which are able to influence the quality of the waters.

The purpose of this study is to determine the quality of the coastal waters of Mimika which focus on the concentration of physical and chemical parameters of the waters according to the water quality standard for marine biota. The results of this study are expected to provide basic information, especially the quality of marine waters as an advice for the management of the coastal and marine areas of Mimika.

\section{MATERIALS AND METHODS}

\section{Study Area}

Mimika is one of the districts in Papua Province, Indonesia. It has complete landscapes from mangroves in coastal areas, peat swamp forests, lowland forests, mountainous areas to ice alpine zones. There are $94 \%$ of the mangrove forests and some other lowland forest types with the range of about $54-97 \%$ being conservation targets (IFACS, 2014). In addition, there are 17 watersheds in Mimika Regency that flow to coastal and marine waters. Mimika Regency waters are part of the Arafura Sea, characterized by dynamic waters with a depth of about 50-80 meters. It also has the potential for high fisheries resources such as demersal fish and several types of shrimp (Pranowo et al., 2013).

This study located in Mimika waters was conducted in October 2016 . The locations for measurement and sampling of seawater include 6 stations, namely (1) Moga waters; (2) Puriri waters; (3) Inaoga waters; (4) Keakwa waters; (5) Atuka waters; and (6) Pomako waters. The sampling location in this study is presented in Figure 1.

\section{Measurement and Analysis of Waters Quality}

The in situ measurement of yjr water quality at each study station was carried out using accredited methods. Meanwhile, the sampling of sea water sample using laboratory analysis. It was conducted by taking sea water samples into polyethylene and $500 \mathrm{~mL}$ glass bottles, with the volume of $350 \mathrm{~mL}, 200 \mathrm{~mL}$ and $100 \mathrm{~mL}$, which were given preservatives, then stored in the coolbox for analysis. The seawater sampling is done based on the Indonesian National Standard (SNI) method No. 6964.8.2015. The sea water samples were analyzed in the BINALAB Laboratory, Bandung. This laboratory was accredited by KAN (National Accreditation Committee). The types of physics and chemistry parameters of seawater were in this study. The measurement methods and standard analysis were presented in Table 1. The data analysis was done by comparing the results of field measurements (in situ) and the results of laboratory analysis with the sea water quality standards based on Minister of Environment Decree No. 51 year 2004 about Sea Water Quality Standards especially the life of marine biota.

\section{Water Pollution Index}

The pollution index is a useful tool to provide information about the water quality. It was determined based on the Decree of the Minister of Environment No. 51 year 2004 using the following forumla (Nemerow and Sumitomo, 1970):

$$
\mathrm{PI}_{\mathrm{j}}=\sqrt{\frac{\left(\mathrm{C}_{\mathrm{i}} / \mathrm{L}_{\mathrm{ij}}\right)_{\mathrm{M}}^{2}+\left(\mathrm{C}_{\mathrm{i}} / \mathrm{L}_{\mathrm{ij}}\right)_{\mathrm{R}}^{2}}{2}}
$$

where: $L_{i j}$ : standard water quality parameter for each parameter at specifed water quality purpose $(\mathrm{j})$

$C_{i}$ : measured water quality parameters $\mathrm{i}$

$P I_{j}$ : the pollution index for a specifed $\mathrm{j}$ water quality purpose (j)

$\left(C_{\mathrm{i}} / L_{i j}\right)_{M}$ : maximum value of $\mathrm{C}_{\mathrm{i}} / \mathrm{L}_{\mathrm{ij}}$

$\left(C_{i} / L_{i j}\right)_{R}$ : average value of $C_{i} / L_{i j}$

The relation between the level of water pollution and the pollution index criteria based on the Decree of the Minister of Environment No. 115 year 2003 about Determination of Water Quality Status is as follows:

$$
\begin{array}{ll}
0 \leq \mathrm{PI}_{\mathrm{j}} \leq 1 & : \text { meets the standard/good quality } \\
1 \leq \mathrm{PI}_{\mathrm{j}} \leq 5 & : \text { lightly polluted } \\
5 \leq \mathrm{PI}_{\mathrm{j}} \leq 10 & : \text { moderately polluted } \\
\mathrm{PI}_{\mathrm{j}}>10 & : \text { heavily polluted }
\end{array}
$$




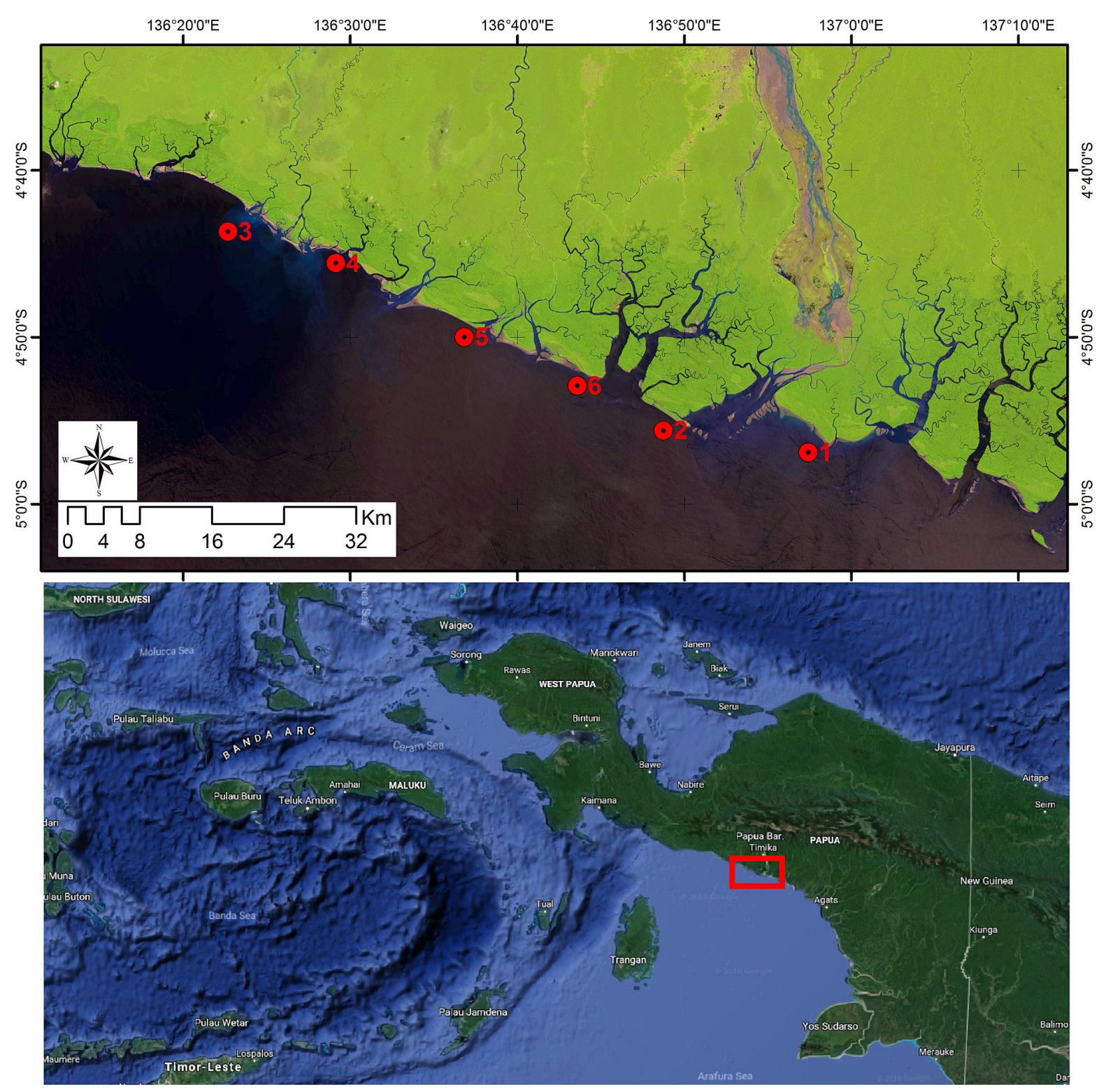

Figure 1. Locations of the sampling stations in coastal waters of Mimika, Indonesia

\section{RESULTS AND DISCUSSION}

\section{Water Quality}

The quality value of marine waters which had been exceeded at the maximum level will be classified as polluted waters. The results of field measurements and laboratory analysis on the quality of Mimika waters using physical and chemical parameters are presented in Table 2. Temperature and salinity water are important factors for the life of organisms in the waters. The results of measurements of the Mimika waters temperature range from 27.5 to $29.3^{\circ} \mathrm{C}$, while salinity ranges from 30.0 to $36.3 \%$. Low salinity at stations 2,4 and 5 was caused bz the entering of huge amount of fresh water through the river. According to the results obtained by Ilahude et al. (2004), the temperature in coastal waters of Timika ranges from 28.0 to $30.0^{\circ} \mathrm{C}$ and slightly lower salinity - from 24.0 to $30.0 \%$. Another study showed that the temperature in Arafura waters ranges to $29.1^{\circ} \mathrm{C}$ and salinity ranges from 24.14 to $33.71 \%$ (Herlisman et al., 2010). The water temperature in this study is the same as the sea surface temperature in the northern waters of Papua which ranges from 25 to $31^{\circ} \mathrm{C}$ and dominant range is from 27 to $29^{\circ} \mathrm{C}$ (Hamuna et al., 2015). According to Decree of the Minister of Environment of the Republic of Indonesia No. 51 year 2004 about sea water quality standards, only the low water temperature at station 3 and station 6 do not comply with 
Table 1. Standard and analytical methods of physicochemical parameters for water quality

\begin{tabular}{|c|c|c|c|}
\hline Parameters & Units & Standards* & Analytical Methods \\
\hline Temperature & ${ }^{\circ} \mathrm{C}$ & $\begin{array}{c}\text { Coral: } 28-30 \\
\text { Mangrove: } 28-32 \\
\text { Seagrass: } 28-30\end{array}$ & APHA 2550 B 2012 \\
\hline Turbidity & NTU & $<5$ & APHA 2130 B 2012 \\
\hline Total Suspended Solid (TSS) & $\mathrm{mg} \mathrm{L}^{-1}$ & $\begin{array}{c}\text { Coral: } 20 \\
\text { Mangrove: } 80 \\
\text { Seagrass: } 20\end{array}$ & APHA 2540 D 2012 \\
\hline $\mathrm{pH}$ & - & $7-8.5$ & APHA $4500 \mathrm{H}+\mathrm{B} 2012$ \\
\hline Salinities & $\%$ & $\begin{array}{c}\text { Coral: } 33-34 \\
\text { Mangrove: up to } 34 \\
\text { Seagrass: } 33-34\end{array}$ & IK-S1 (Salt meter) \\
\hline Dissolved Oxygen (DO) & $\mathrm{mg} \mathrm{L}^{-1}$ & $>5$ & IK-S2 (DO meter) \\
\hline $\begin{array}{l}\text { Biochemical Oxygen Demand } \\
\text { (BOD) }\end{array}$ & $\mathrm{mg} \mathrm{L}^{-1}$ & 20 & APHA 5210 B 2012 \\
\hline Ammonia Total $\left(\mathrm{NH}_{3}\right)$ & $\mathrm{mg} \mathrm{L}^{-1}$ & 0.3 & SNI 19-6964.3-2003 \\
\hline Nitrate $\left(\mathrm{NO}_{3}\right)$ & $\mathrm{mg} \mathrm{L}^{-1}$ & 0.008 & SNI 19-6964.7-2003 \\
\hline Phosphate $\left(\mathrm{PO}_{4}\right)$ & $\mathrm{mg} \mathrm{L}^{-1}$ & 0.015 & SNI 06-6989.31-2005 \\
\hline Sulfide $\left(\mathrm{H}_{2} \mathrm{~S}\right)$ & $\mathrm{mg} \mathrm{L}^{-1}$ & 0.1 & SNI 19-6964.4-2003 \\
\hline Mercury $(\mathrm{Hg})$ & $\mathrm{mg} \mathrm{L}^{-1}$ & 0.001 & IK-L 42-MP-AES \\
\hline Arsenic (As) & $\mathrm{mg} \mathrm{L}^{-1}$ & 0.012 & IK-L 42-MP-AES \\
\hline Cadmium (Cd) & $\mathrm{mg} \mathrm{L}^{-1}$ & 0.001 & APHA 3111 B 2012 \\
\hline Lead $(\mathrm{Pb})$ & $\mathrm{mg} \mathrm{L}^{-1}$ & 0.008 & APHA 3111 B 2012 \\
\hline Copper (Cu) & $\mathrm{mg} \mathrm{L}^{-1}$ & 0.008 & APHA 3111 B 2012 \\
\hline Zinc (Zn) & $\mathrm{mg} \mathrm{L}^{-1}$ & 0.05 & APHA 3111 B 2012 \\
\hline Nickel (Ni) & $\mathrm{mg} \mathrm{L}^{-1}$ & 0.05 & APHA 3111 B 2012 \\
\hline Chromium (Cr) & $\mathrm{mg} \mathrm{L}^{-1}$ & 0.05 & APHA 3111 B 2012 \\
\hline
\end{tabular}

Remarks: *Minister of Environment Decree No. 51 year 2004 about Seawater Quality Standards for Marine Biota

Table 2. The physicochemical parameters in coastal waters of Mimika, Indonesia

\begin{tabular}{|c|c|c|c|c|c|c|}
\hline \multirow{2}{*}{ Parameters } & \multicolumn{6}{|c|}{ Stations } \\
\hline & St. 1 & St. 2 & St. 3 & St. 4 & St. 5 & St. 6 \\
\hline Temperature $\left({ }^{\circ} \mathrm{C}\right)$ & 28.3 & 29.3 & 27.5 & 29.3 & 28.1 & 27.8 \\
\hline Turbidity (NTU) & 0.49 & 0.19 & 1.32 & 0.16 & 1.33 & 0.63 \\
\hline TSS (mg L-1) & 13 & 6.67 & 17.43 & 28 & 13.71 & 8.57 \\
\hline $\mathrm{pH}$ & 6.5 & 6.7 & 7.3 & 7.6 & 6.9 & 6.7 \\
\hline Salinities (\%o) & 35.4 & 30.4 & 36.3 & 30 & 30.1 & 32 \\
\hline $\mathrm{DO}\left(\mathrm{mg} \mathrm{L}^{-1}\right)$ & 4.7 & 4.7 & 4.4 & 4.6 & 5.2 & 5.2 \\
\hline $\mathrm{BOD}\left(\mathrm{mg} \mathrm{L}^{-1}\right)$ & 0.27 & 0.3 & 0.18 & 0.29 & 0.24 & 1.08 \\
\hline $\mathrm{NH}_{3}\left(\mathrm{mg} \mathrm{L}^{-1}\right)$ & 0.1 & 0.05 & 0.1 & 0.1 & 0.07 & 0.18 \\
\hline $\mathrm{NO}_{3}\left(\mathrm{mg} \mathrm{L}^{-1}\right)$ & 0.32 & 0.04 & 0.07 & 0.07 & 0.3 & 0.08 \\
\hline $\mathrm{PO}_{4}\left(\mathrm{mg} \mathrm{L}^{-1}\right)$ & 0.13 & 0.37 & 0.85 & 0.14 & 0.09 & 0.02 \\
\hline $\mathrm{H}_{2} \mathrm{~S}\left(\mathrm{mg} \mathrm{L}^{-1}\right)$ & 0.04 & 0.03 & 0.04 & 0.06 & 0.06 & 0.06 \\
\hline $\mathrm{Hg}\left(\mathrm{mg} \mathrm{L}^{-1}\right)$ & $<0.0008$ & $<0.0008$ & $<0.0008$ & $<0.0008$ & $<0.0008$ & $<0.0008$ \\
\hline As $\left(\mathrm{mg} \mathrm{L}^{-1}\right)$ & $<0.006$ & $<0.006$ & $<0.006$ & $<0.006$ & $<0.006$ & $<0.006$ \\
\hline $\mathrm{Cd}\left(\mathrm{mg} \mathrm{L}^{-1}\right)$ & $<0.0006$ & $<0.0006$ & $<0.0006$ & $<0.0006$ & $<0.0006$ & $<0.0006$ \\
\hline $\mathrm{Pb}\left(\mathrm{mg} \mathrm{L}^{-1}\right)$ & $<0.006$ & $<0.006$ & $<0.006$ & $<0.006$ & $<0.006$ & $<0.006$ \\
\hline $\mathrm{Cu}\left(\mathrm{mg} \mathrm{L}^{-1}\right)$ & $<0.006$ & $<0.006$ & $<0.006$ & $<0.006$ & $<0.006$ & $<0.006$ \\
\hline $\mathrm{Zn}\left(\mathrm{mg} \mathrm{L}^{-1}\right)$ & $<0.02$ & $<0.02$ & $<0.02$ & $<0.02$ & $<0.02$ & $<0.02$ \\
\hline $\mathrm{Ni}\left(\mathrm{mg} \mathrm{L}^{-1}\right)$ & $<0.04$ & $<0.04$ & $<0.04$ & $<0.04$ & $<0.04$ & $<0.04$ \\
\hline $\mathrm{Cr}\left(\mathrm{mg} \mathrm{L}^{-1}\right)$ & $<0.004$ & $<0.004$ & $<0.004$ & $<0.004$ & $<0.004$ & $<0.004$ \\
\hline
\end{tabular}

Remarks: smaller marks $(<)$ are below the detection limit: $0.0008 \mathrm{mg} \mathrm{L}^{-1}$ for $\mathrm{Hg} ; 0.006 \mathrm{mg} \mathrm{L}^{-1}$ for As; $0.0006 \mathrm{mg}$ $\mathrm{L}^{-1}$ for $\mathrm{Cd}$; $0.006 \mathrm{mg} \mathrm{L}^{-1}$ for $\mathrm{Pb} ; 0.006 \mathrm{mg} \mathrm{L}^{-1}$ for $\mathrm{Cu} ; 0.02 \mathrm{mg} \mathrm{L}^{-1}$ for $\mathrm{Zn} ; 0.04 \mathrm{mg} \mathrm{L}^{-1}$ for $\mathrm{Ni}$; $0.004 \mathrm{mg} \mathrm{L}^{-1}$ for $\mathrm{Cr}$ 
sea water quality standards for the life of marine biota. Meanwhile, the results of measurements of water salinity show that salinity at all study stations does not comply with sea water quality standards for marine biota life (coral and seagrass), but it is still appropriate for mangrove growth. Although the water temperature and salinity in some study stations did not appropriate with the quality standards, the changes of temperature to $<2^{\circ} \mathrm{C}$ from natural temperatures and $<5 \%$ seasonal salinity can be allowed.

The value of $\mathrm{pH}$ is another important parameter used for monitoring the stability of the waters. The $\mathrm{pH}$ conditions of water are closely related to carbon dioxide $\left(\mathrm{CO}_{2}\right)$ and alkalinity. It means that the higher the $\mathrm{pH}$, the higher the alkalinity and the lower levels of free $\mathrm{CO}_{2}$ (Mackereth et al., 1989). The value of $\mathrm{pH}$ in this study ranges from 6.5 to 7.6 and the $\mathrm{pH}$ of Indonesian sea surface water with ranges from 6.0 to 8.5 (Romimohtarto and Juwana, 2001). The $\mathrm{pH}$ can be affected by biological activity, photosynthesis, temperature, oxygen content, and the cations and anions (Pescond, 1973). In addition, the increasing concentrations of $\mathrm{CO}_{2}$ in the atmosphere can cause acidification of marine waters (Fabry et al., 2008). The result of this study showed that the $\mathrm{pH}$ value of the waters at station 3 and station 4 appropriate to growth of marine biota optimally. Although the $\mathrm{pH}$ of the waters in other research stations did not appropriate with the quality standard, it still can be allowed to change at $<0.2 \mathrm{pH}$ unit (Minister of Environment, 2004).

The ability of sunlight to penetrate the bottom of the waters is influenced by turbidity and TSS (Widiadmoko, 2013). The turbidity level of Mimika waters in this study is classified low, which ranges from 0.19 to 1.33 NTU. The level of turbidity is appropriate with the quality standards for marine biota. It differs from the results of the study by Ilahude et al. (2004) which showed that the levels of turbidity in Arafura waters is highly varied between 11 to 14 NTU in coastal waters, $750 \mathrm{NTU}$ in estuaries and 5.0 to $6.0 \mathrm{NTU}$ in offshore waters. The results of the TSS analysis showed that the values varied from 6.67 to $28.0 \mathrm{mg} \mathrm{L}^{-1}$. According to the results of TSS analysis, the Mimika waters are appropriate to the marine life based on the quality standard except at station 4 is high and did not appropriate to coral and seagrass growth.

The water organisms that dissolve oxygen are relatively varied and depending on type, stage and activity. The DO and BOD parameters are important to determine the quality of waters. DO shows the total amount of dissolved oxygen in the waters for breathing and metabolic processes, while BOD shows the amount of dissolved oxygen needed by microorganisms to decompose or decompose organic matter under aerobic conditions (Salmin, 2005). The results of The Mimika waters DO analysis ranges from 4.4 to $5.2 \mathrm{mg}$ $\mathrm{L}^{-1}$ and low BOD ranges from $0.18-1.08 \mathrm{mg} \mathrm{L}^{-1}$. The DO in this study was higher than the DO in the study of Pranowo et al. (2013) which showed that Arafura waters DO range from 2.30 to 4.35 $\mathrm{mg} \mathrm{L}^{-1}$. The results of this study indicate that the DO and BOD of the Mimika waters are appropriate to support the life of marine biota, although the DO at stations 1 to station 4 is low, but still tolerable. According to Swingle (1967), the minimum DO of marine waters is $2 \mathrm{mg} \mathrm{L}^{-1}$ under normal conditions and it is not contaminated by toxic compounds, thus being sufficient to support the life of the organism.

The other influential quality water parameters are the concentration of nutrients in the waters, such as Ammonia $\left(\mathrm{NH}_{3}\right)$, Nitrate $\left(\mathrm{NO}_{3}\right)$, Phosphate $\left(\mathrm{PO}_{4}\right)$ and Sulfide $\left(\mathrm{H}_{2} \mathrm{~S}\right) . \mathrm{NH}_{3}$ is one of the common chemicals contained in waste (Bonnin et al., 2008). The $\mathrm{NH}_{3}$ concentration in marine waters is varied and it can be toxic to marine biota if the concentration exceeds the maximum threshold. The $\mathrm{NH}_{3}$ concentrations in Mimika waters range from 0.05 to $0.18 \mathrm{mg} \mathrm{L}^{-1}$ and appropriate with the quality standards for marine biota. This concentration is low, comparing with the concentration of $\mathrm{NH}_{3}$ in other waters in Papua, such as in Depapre-Jayapura waters which the range from 0.8 to $11.6 \mathrm{mg} \mathrm{L}^{-1}$ (Hamuna et al., 2018).

$\mathrm{NO}_{3}$ and $\mathrm{PO}_{4}$ are important nutrient compounds in waters. $\mathrm{NO}_{3}$ is the most stable form of inorganic nitrogen in oxygenated water (AbdelHalim and Aly-Eldeen, 2016). The $\mathrm{NO}_{3}$ and $\mathrm{PO}_{4}$ concentrations in Mimika waters exceeded the quality standards based on the Decree of the Minister of Environment of the Republic of Indonesia No. 51 year 2004 for marine biota. The $\mathrm{NO}_{3}$ and $\mathrm{PO}_{4}$ concentrations around the Mimika waters were by Pranowo et al. (2013). It showed that high concentrate range from 0.22 to $18.31 \mathrm{mg} \mathrm{L}^{-1}$ for $\mathrm{NO}_{3}$ and 0.15 to $1.50 \mathrm{mg} \mathrm{L}^{-1}$ for $\mathrm{PO}_{4}$. The high $\mathrm{NO}_{3}$ and $\mathrm{PO}_{4}$ concentration in waters can make an eutrophication or population explosion. All nutrient almost compounds $\left(\mathrm{NO}_{3}\right.$ and $\left.\mathrm{PO}_{4}\right)$ in marine waters and sourced from river flows which gen- 
erated by agricultural, aquaculture, industrial and household or waste activities population (Cloern, 2001; Casali et al., 2007).

Similarly to the $\mathrm{NO}_{3}$ and $\mathrm{PO}_{4}$ concentrations, the $\mathrm{H}_{2} \mathrm{~S}$ concentrations in the waters exceeded the quality standards. The results of $\mathrm{H}_{2} \mathrm{~S}$ concentration analysis range from 0.03 to $0.06 \mathrm{mg} \mathrm{L}^{-1}$. According to Poppo et al. (2012), the source of high concentrations of $\mathrm{H}_{2} \mathrm{~S}$ in the waters stems from decomposition process of organic materials which contain of sulfur by anaerobic and $-\mathrm{a}$ result of reduction- anaerobic conditions against sulfates by microorganisms. The $\mathrm{H}_{2} \mathrm{~S}$ concentration varies based on season and $\mathrm{H}_{2} \mathrm{~S}$ can affect the cycle of some trace metals in the waters (Cutter and Krahforst, 1988).

According to the results of heavy metal content analysis in the Mimika waters, the content of heavy metals ( $\mathrm{Hg}, \mathrm{As}, \mathrm{Cd}, \mathrm{Pb}, \mathrm{Cu}, \mathrm{Zn}, \mathrm{Ni}$ and $\mathrm{Cr}$ ) in all station was low (below detection limit). That is why the content of heavy metal in the Mimika waters is safe for marine biota. Compared with some waters in Indonesia, the content of heavy metals dissolved in waters exceeded the quality standards for marine biota. For example, the heavy metal content of $\mathrm{Pb}(0.6037$ to $0.6647 \mathrm{mg}$ $\left.\mathrm{L}^{-1}\right)$ and $\mathrm{Cu}\left(0.064\right.$ to $\left.0.1707 \mathrm{mg} \mathrm{L}^{-1}\right)$ in the waters of Demak, Central Java exceeded the quality standards for marine biota (Tjahjono and Suwarno, 2018). For some cases in the waters of Madura, East Java (Apriani et al., 2018) the heavy metal content of $\mathrm{Pb}$ reached $\left(0.07\right.$ to $\left.0.42 \mathrm{mg} \mathrm{L}^{-1}\right)$ and $\mathrm{Cu}\left(0.08\right.$ to $\left.1.56 \mathrm{mg} \mathrm{L}^{-1}\right)$. In addition, the heavy metal content of $\mathrm{Pb}\left(0.013\right.$ to $\left.0.084 \mathrm{mg} \mathrm{L}^{-1}\right)$ and
Cd (0.032 to $\left.0.071 \mathrm{mg} \mathrm{L}^{-1}\right)$ in Ambon waters also exceeded the quality standards for marine biota (Tupan and Uneputty, 2017). Furthermore, the heavy metal content of $\mathrm{Cr}\left(0.14\right.$ to $\left.0.16 \mathrm{mg} \mathrm{L}^{-1}\right)$ exceeded the quality standards in Tugu coastal waters, Semarang (Suryono and Rochaddi, 2013). The heavy metal pollution from industry, domestic activities, transportation and natural sources from rocks flow to the river or ocean waters and accumulate in the waters and marine biota. The heavy metals in waters at certain concentrations will change their function to toxic to the life of waters (Murtini et al., 2001).

\section{Water Pollution Index}

Most studies about the water quality assessment use a water quality index (Dunca, 2018). The water pollution index provides a single assessment score on the environmental parameters and it will be analyzed to interpret the water quality (Popovic et al., 2016). The water pollution index can be used to determine the level of water pollution in coastal areas. The results of the pollution index calculation can give an advice to the decision makers in order to assess the quality of waters and improve the quality of water if there is a quality reduction due to the existence of pollutant compounds. The results from the analysis of the pollution index values at each station are fully presented in Figure 2.

According to the results of the pollution index calculation in Figure 2, it can be seen that all observation stations are characterized by mild

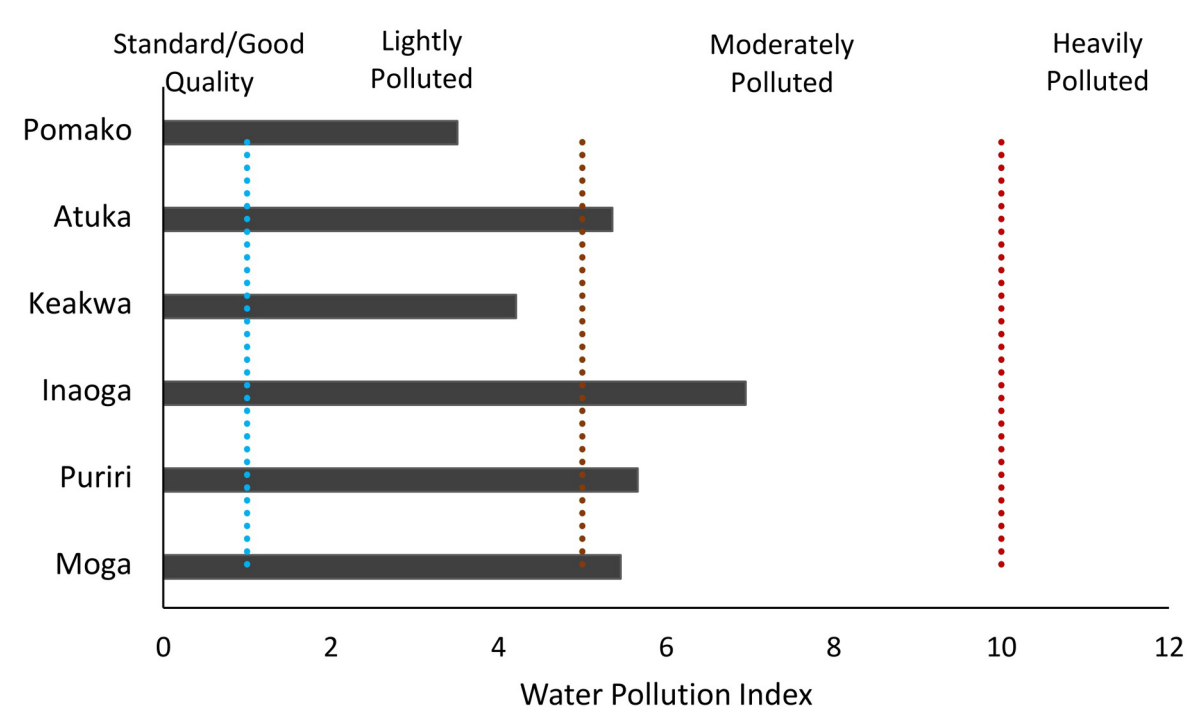

Figure 2. Water pollution index in coastal waters of Mimika, Indonesia 
to moderate polluted conditions, where only the waters of Keakwa and Pomako are categorized as lightly polluted with a pollution index value of 4.21 and 3.51, respectively. Moga, Puriri, Inaoga and Atuka waters are in the moderately polluted category with the pollution index values of 5.46, 5.66, 6.95 and 5.36, respectively. According to the results of water quality analysis, the paramaters of quality standards for marine biota such as $\mathrm{pH}$, salinity, $\mathrm{DO}, \mathrm{NO}_{3}, \mathrm{PO}_{4}$ and $\mathrm{H}_{2} \mathrm{~S}$, are exceeded. This condition Has become an issue because $\mathrm{NO}_{3}, \mathrm{PO}_{4}$ and $\mathrm{H}_{2} \mathrm{~S}$ are environmental parameters with contain nutrient element. If figh concentrations of nutrients accumulate and increase in marine waters, they cause danger the eutrophication for marine biota (Hamuna et al., 2018).

\section{CONCLUSIONS}

The parameters of water environment consisting of water turbidity, $\mathrm{BOD}, \mathrm{NH}_{3}$ and heavy metals ( $\mathrm{Hg}, \mathrm{As}, \mathrm{Cd}, \mathrm{Pb}, \mathrm{Cu}, \mathrm{Zn}, \mathrm{Ni}$ and $\mathrm{Cr}$ ) are within the standards quality for marine biota in all study stations. Water temperature did not meet the quality nails in the waters of Inaoga and Pomako. TSS exceeded the quality standards for coral and seagrass in the waters of Keakwa, the $\mathrm{pH}$ of the waters did not appropriate with the quality standards in the waters of Moga, Puriri, Atuka and Pomako, while DO did not agree with the standards quality in Moga, Puriri, Inaoga and Keakwa waters. There are parameters that exceeded quality standards in all study locations such as water salinity for coral and seagrass, $\mathrm{NO}_{3}, \mathrm{PO}_{4}$ and $\mathrm{H}_{2} \mathrm{~S}$. It became a concern that most of the parameters exceeded the quality standards for marine biota such as $\mathrm{pH}$, salinity, $\mathrm{DO}, \mathrm{NO}_{3}, \mathrm{PO}_{4}$ and $\mathrm{H}_{2} \mathrm{~S}$ parameters. This condition is becoming an issue because $\mathrm{NO}_{3}, \mathrm{PO}_{4}$ and $\mathrm{H}_{2} \mathrm{~S}$ are environmental parameters that contain element nutrients which can lead to eutrophication in the water.

On the basis of the results of the pollution index calculation, the Mimika waters are classified as lightly polluted to moderately polluted with pollution index values of 3.51 to 6.95 . The waters of Keakwa and Pomako ware categorized as lightly polluted, while the waters of Moga, Puriri, Inaoga and Atuka are moderately polluted. It can be concluded that using the water pollution index can provide information on water quality such as the level of water pollution.

\section{REFERENCES}

1. Abdel-Halim A.M., Aly-Eldeen M.A. 2016. Characteristics of Mediterranian sea water in vicinity of Sidikerir region, west of Alexandria, Eqypt. Eqyptian Journal of Aquatic Research, 42, 133-140.

2. Apriani M., Hadi W., Masduqi A. 2018. Physicochemical properties of sea water and bittern in Indonesia: Quality improvement and potential resources utilization for marine environmental sustainability. Journal of Ecological Engineering, 19(3), 1-10.

3. Bonnin E.P., Biddinger E.J., Botte G.G. 2008. Effect of catalyst on electrolysis of ammonia efflents. Journal of Power Sources, 182, 284-290.

4. Casali J.R., Gimenez J., Diez J., Álvarez Mozos J., de Lersundi D.V., Goni M., Campo M. A., Chahor Y., Gastesi R., Lopez J. 2010. Sediment production and water quality of watersheds with contrasting land use in Navarre (Spain). Agricultural Water Management, 97, 1683-1694.

5. Chen C.W., Kao C.M., Chen C.F., Dong C.D. 2007. Distribution and accumulation of heavy metals in sediments of kaoshiung harbor. Chemosphere, 66: 1431-1440.

6. Cloern J.E. 2001. Our Evolving conceptual model of the coastal eutrophication problem. Marine Ecology Progress Series, 210, 223-253.

7. Cutter G.A., Krahforst C.F. 1988. Sulfide in surface waters of the western Atlantic Ocean. Geophysical Research Letters, 15(2), 1393-1396.

8. Drira Z., Sahnoun H., Ayadi H. 2017. Spatial distribution and source identifcation of heavy metals in surface waters of three coastal areas of Tunisia. Polish Journal of Environmental Studies, 26(3), 1057-1069.

9. Dunca A.M. 2018. Water pollution and water quality assessment of major transboundary rivers from Banat (Romania). Journal of Chemistry, 2018, 1-8.

10. Fabry V.J., Seibel B.A., Feely R.A., Orr J.C. 2008. Impact of ocean acidification on marine fauna and ecosystem processed. University of Rhode Island, Kingston.

11. Hamuna B., Paulangan Y.P., Dimara L. 2015. Study of sea surface temperature using Aqua-MODIS satellite data in Jayapura waters, Papua. Depik, 4(3), 160-167. (in Indonesian)

12. Hamuna B., Tanjung R.H.P., Suwito, Maury H.K. 2018. Study of sea water quality and pollution index based on physical-chemical parameters in Depapre District waters, Jayapura. Jurnal Ilmu Lingkungan, 16(1), 35-43. (in Indonesian)

13. Herlisman, Tubalawony S., Ramdhan M., Talakua B.F. 2010. Physical oceanography. Chapter II in ATSEA Cruise Report, 2nd Edition, in S. Wiras- 
antosa, T. Wagey, S. Nurhakim and D. Nugroho (eds.). ATSEA Program.

14. Ilahude A.G., Hortle K., Kusmanto E., Amiruddin. 2004. Oceanography of coastal and riverine waters around Timika, West Central Irian Jaya, Arafura Sea. Continental Shelf Research, 24(19), 2511-2520.

15. Indonesia Forest and Climate Support (IFACS). 2014. Landscape Conservation Plan for Mimika District, Papua Province. USAID-Indonesia Forest and Climate Support, Indonesia. (in Indonesian).

16. Mackereth F.J.H., Heron J., Talling J.F. 1989. Water analysis. Fresh Water Biological Association, UK.

17. Minister of Environment. 2003. Decree of the Minister of Environment No. 51 year 2004 about Guidelines on Water Quality Status Determination. Minister of Environment of the Republic Of Indonesia, Jakarta. (In Indonesian).

18. Minister of Environment. 2004. Decree of the Minister of Environment No. 51 year 2004 about Water Quality Standard for Coastal water. Minister of Environment of the Republic Of Indonesia, Jakarta. (In Indonesian).

19. Murtini J.T., Ariyani F., Wahyuni I.S., Hak N., Suherman M., Dolaria N., Nurwiyanto. 2001. Inventory research and identification of heavy metal pollution in waters and fish. Technical Report. Pusat Riset Pengolahan Produk dan Bioteknologi Kelautan dan Perikanan. Jakarta. (in Indonesian).

20. Nemerow N.L. Sumitomo H. 1970. Benefts of water quality enhancement. Report no. 16110 DAJ, prepared for the U.S. Environmental Protection Agency.

21. Pescond M.B. 1973. Investigation of rational effluent and stream standard for tropical countries. Asian Institute Technology, Bangkok.

22. Popovic N.Z., Diknic J.A., Atlagic J.Z.C., Rakovic M.J., Marinkovis N.S., Tubic B.P., Paunovic M.M. 2016. Application of the water pollution index in the assessment of the ecological status of rivers: a case study of the Sava River, Serbia. Acta Zoologica Bulgarica, 68(1), 97-102.

23. Poppo A., Mahendra M.S., Sundra I.K. 2012. Study of coastal waters quality in fisheries industry area, Pengambengan Village, Negara District, Jembrana Regency. Ecotrophic, 3(2), 98-103. (in Indonesian).

24. Pranowo W.S., Wirasantosa S., Amri S.N., Dewi L.C., Ratnawati H.I., Ati R.N.A., Prihantono J., Makarim S., Hutahean A.A. 2013. Characteristics of Arafura marine resources and southwest coast of Papua. Research and Development Center for Marine and Coastal Resources, Ministry of Maritime Affairs and Fisheries, Jakarta. (in Indonesian).

25. Romimohtarto K., Juwana S. 2001. Marine biology: Science about marine biota. Puslitbang Oseanologi LIPI, Jakarta. (in Indonesian).

26. Salmin. 2005. Dissolved oxygen (DO) and biological oxygen demand (BOD) as indicator to determine water quality. Oseana, 30(3), 21-26. (in Indonesian).

27. Suryono C.A., Rochaddi B. 2013. Connectivity heavy metals in shallow groundwater, sediment and seawater in coastal area. Ilmu Kelautan, 18(2), 91-96. (in Indonesian).

28. Swingle H.S. 1967. Standardization of chemical analysis for water and pond muds. FAO Fish Rep., 4(44), 397-421.

29. Tjahjono A., Bambang A.N., Anggoro S. 2017. Analysis of heavy metal content of $\mathrm{Pb}$ in ballast water tank of commercial vessels in port of Tanjung Emas Semarang, Central Java Province. Journal of Ecological Engineering, 18(2), 7-11.

30. Tjahjono A., Suwarno D. 2018. The spatial distribution of heavy metal lead and cadmium pollution and coliform abundance of waters and surface sediment in Demak. Journal of Ecological Engineering, 19(4), 43-54.

31. Tupan C.I., Uneputty P.A. 2017. Concentration of heavy metals lead $(\mathrm{Pb})$ and cadmium $(\mathrm{Cd})$ in water, sediment and seagrass Thalassia hemprichii in Ambon Island waters. AACL Bioflux, 10(6), 1610-1617.

32. Widiadmoko W. 2013. Physical and chemical water quality monitoring in Hurun Bay waters. Balai Besar Pengembangan Budidaya Laut (BBPBL) Lampung, Bandar Lampung. (in Indonesian). 